\title{
PARAMETRIZED KLAMKIN'S INEQUALITY AND IMPROVED EULER'S INEQUALITY
}

\author{
DARKO VELJAN AND SHANHE Wu
}

\begin{abstract}
In this paper, the authors present a generalization of Klamkin's inequality by introducing a parameter, which relaxes the conditions of Klamkin's inequality. As applications, some improved versions of Euler's inequality are obtained.
\end{abstract}

Mathematics subject classification (2000): 26D05, 26D15, 51M16.

Key words and phrases: Klamkin's inequality; Euler's inequality; Băndilǎ's inequality; parameter; sharpening; generalization.

\section{REFERENCES}

[1] P. M. VAsić, Some inequalities for the triangle, Univ. Beograd. Publ. Elektrotehn. Fak. Ser. Mat. Fiz. 274-301(1969), 121-126.

[2] M. S. Klamkin, On a triangle inequality, Crux Math. 10 (1984), 139-140.

[3] D. S. Mitrinović, J. E. PEČARIĆ AND V. VOLENEC, Recent Advances in Geometric Inequalities. Kluwer Academic Publishers, Dordrecht, Netherlands, 1989.

[4] D. S. Mitrinović AND P. M. VAsić, Analytic Inequalities, Springer-Verlag, New York, 1970.

[5] O. BotTeMa, R. Z. DJordjević, R. R. Janić, D. S. Mitrinović AND P. M. VAsić, Geometric Inequalities. Wolters-Noordhoff, Groningen, 1969.

[6] D. S. Mitrinović, J. E. PeČArić, V. Volenec And J. Chen, Addenda to the Monograph: Recent Advances in Geometric Inequalities(I). Journal of Ningbo University, 4(2)(1991).

[7] Z. SHAN, Geometric Inequality in China. Jiangsu Education Publishing House, Nanjing, 1996 (in Chinese).

[8] J.-CH. KuANG, Applied Inequalities, 2nd ed., Shandong Science and Technology Press, Jinan, 2004 (in Chinese).

[9] S. WU, Generalization and sharpness of Finsler-Hadwiger's inequality and its applications. Math. Inequal. Appl., 9 (3) (2006), 421-426.

[10] SH.-H. WU, A sharpened Euler's inequality and its inverse version. The Monthly Journal of High School Mathematics, 1 (2003).19-20 (in Chinese).

[11] SH.-H. WU AND ZH.-H. ZHANG, A class of inequalities related to the angle bisectors and the sides of a triangle. J. Inequal. Pure Appl. Math., 7 (3) (2006), Article 108.

[12] R. A. Satnolanu, General power inequalities between the sides and the circumscribed and inscribed radii related to the fundamental triangle inequality. Math. Inequal. Appl., 5(4)(2002),745-751.

[13] R. A. SATNOIANU, Refined geometric inequalities between two or more triangles obtained by dedublation. Math. Inequal. Appl., 7(2)(2004),289-298.

[14] V. BăndiĽ̆, Problem C 474, Gaz. Mat. (Bucharest) 90 (1985), 65.

[15] ZH.-H. ZhANG, Q. Song AND ZH.-S. WANG, Some Strengthened Results On Euler's Inequality. RGMIA Res. Rep. Coll. 6 (4) (2003), Art. 7, Available online at URL: http://rgmia.vu.edu.au/v6n4.html.

[16] D. SVRTAN AND I. URBIHA, Verification and strengthening of the Atiyah-Sutcliffe conjectures for several types of configurations, arXiv: math. MG/0609174 v1, 6 Sep 2006. 